\title{
Disorderly Deliberation? Generative Dynamics of Global Climate Justice
}

\author{
James Goodman, University of Technology Sydney
}

Since its inception, official climate governance has hinged on perceptions of climate justice. Under the rubric of 'common but differentiated responsibility,' the 1992 Framework Convention on Climate Change and the ensuing Kyoto Protocol have had their main impact on signatories that are high-emitting industrialized countries. The thirty-seven 'Developed Countries' listed in 'Annex 1' of the Convention had a special obligation to take the lead in reducing greenhouse gas emissions (Patterson and Grubb 1992). ${ }^{1}$ Under the 1997 Kyoto Protocol these countries agreed to reduce greenhouse gas emissions by 5.2 per cent below 1990 levels, and to do this by 2012. With the upcoming expiry of Kyoto commitments, there is an urgent requirement for a new climate governance package deal (Depledge 2006). As a result, climate justice is firmly back on the agenda, and in new ways, as manifested from the highest elite levels of global climate negotiation to the most grassroots challenges to climate policy. The configuration of climate governance post-2012, and indeed its effectiveness, centres on these contestations over the meaning of climate justice, and its official re-articulations. Current climate governance, and its future configuration, thus has to be understood as a reflexive and dynamic process. As with any form of interstate governance, global climate policy seeks stabilized principles to drive its inter-governmental 'rules of the game.' Yet, forced to address the exponential challenges of climate change, and its

\footnotetext{
${ }^{1}$ There are now 40 countries in the Annex 1 group, which includes the European Union; this article refers to the group as 'Annex 1 Countries.'

PORTAL Journal of Multidisciplinary International Studies, vol. 8, no. 3, September 2011. Special issue details: Global Climate Change Policy: Post-Copenhagen Discord Special Issue, guest edited by Chris Riedy and Ian McGregor. 
associated implications for justice, these principles must be subject to disordering challenges, and to reordering. There is an imperative to move beyond immediate accommodations, with new rules of the game to more effectively apprehend the challenges posed. Here, the mechanisms of disorderly deliberation become critical. The approach taken in this paper positions such disorder, centring on a contest over the meaning of climate justice, at the core of global climate governance.

Climate governance, it may be argued, is not qualitatively dissimilar from other forms of global governance. All forms of official governance respond to some felt need, and as perceptions of that need changes, so the governance framework changes. But climate change poses special challenges, similar in scale perhaps to Cold War governance. There, the confrontation between communism and capitalism was a systemic confrontation, reflecting global-scale social contradictions, which posed the possibility of planetary annihilation, in this case through a 'nuclear winter.' Climate change likewise expresses a global systemic contradiction, in this case an ecological contradiction between climate stability and accumulation. Like the nuclear stand-off, climate change is also totalizing, and poses the possibility of making the planet uninhabitable. The key difference is that under the Cold War the two key players could negotiate with one another, to ward off annihilation: the USA and the Soviet Union could construct governance structures, as expressed in the notion of détente, to manage the confrontation. In contrast, there is no negotiating with climate change: there is no 'hot line' to manage eco-social relations. Where the Cold War could be managed through the threat of 'Mutually Assured Destruction,' every effort at managing climate change, rather than addressing its causes, brings us closer to the possibility of catastrophic change.

In this respect, governance structures that secure managerial 'sub-paradigmatic' adaptations to existing arrangements are counterproductive, and serve only to prefigure the required paradigmatic transformations (Sousa Santos 1995). Here, questions of reflexive governance are both urgent and fundamental. As the existing carbon-intensive social paradigm reaches its limits we are witnessing various efforts at managing the transition through global carbon markets and the application of technology (Stern 2007; Parry et al. 2007; Lohmann 2006). While efforts to address the problem prove inadequate, climate change has intensified, forcing new targets and approaches onto the 
table (Christoff 2006; Dorsey 2007). The resulting disorderly transition marks an interregnum in sociological terms, a period of social and political flux, and potential (Sousa Santos 1995). Indeed with the advent of climate crisis we see the emergence of a deep-seated challenge to society's underlying historicity: the crisis literally imperils survival for human society, and insofar as carbon-intensive development underpins social structures, the prospect of de-carbonization challenges the very foundation of prevailing norms and hierarchies.

The systemic ecological challenge posed by climate change, and its intensification, forces the agenda for climate governance. Models for addressing the crisis from within market capitalism have proved to be woefully inadequate; yet they have persisted. Weak forms of 'ecological modernization,' centred on carbon trading and end-of-pipe technologies, for instance, continue to dominate. Stronger forms of intervention, through fiscal policy and direct regulation for renewables, posit a 'second modernity,' with growth de-carbonized by 'precautionary' technologies and institutional practices (Beck 1995; Blowers 1997; Moll 2000). Yet the decoupling of economic growth from ecological degradation as promoted by ecological modernizers has become more of a fond hope than a present possibility. On a world scale, emissions continue to rise exponentially, testament to the paradox that every reduction in emissions intensity is more than overwhelmed by the increased scale of activity that it enables, as expressed in global economic growth.

As ecological modernity falters in the face of persistently rising emissions, confronted with questions of growth and accumulation, it has quickly been overtaken by a revived denialism and a reactive securitization of the issue. There is, as a result, a deepened polarization of the policy field. Those defending the growth model, whether or not offering the means of emissions reduction, confront those rejecting it. The latter perspective encompasses a range of positions, from ecological sufficiency to ecological socialism and ecological feminism, and may be linked to 'post-developmentalist' and 'subsistence' perspectives (Salleh 1997; Bennholdt-Thomsen \& Mies 1999; Hornborg 2001; Foster-Carter 2002; Ziai 2007; Kovel 2007). These psotions share the recognition that climate change requires a post-growth society, and that this necessarily entails the large-scale restructuring of social relations. As ecological modernization fails to remaster ecology for society, we are left with a clear choice: continued burden-shifting 
and technological optimism, versus an entirely new ecology-society nexus (Harvey 1996).

These policy confrontations play a central role in the intensifying political dynamics of climate justice. The failure of the current model of climate governance is a key factor legitimizing challenges to its 'rules of the game.' Indeed, we may say that we sit on the cusp of a paradigm-shift, one that forces awareness of humanity's planetary agency, and thus awareness of its role in the face of eco-systemic impacts. The 'Anthropocene' era, in which humankind has had the capacity to reshape the bio-physical character of the planet, is said to have been in place since the invention of the steam engine (Crutzen 2002). With the documented impacts of human-generated climate change, as expressed in climate science, that capacity translates into an imperative for global reflexivity. The result is a profound clash between what Chakrabarty characterizes as the history of humanity, the recorded histories of human justice, and the history of the species as expressed in climate science (2008). As historical time confronts geological time, global climate governance is invoked as the required mediating instrument, bridging human justice and climate impacts. As a site of global governance, then, climate governance embodies the possibility, and indeed necessity of defining and pursuing global climate reflexivity.

\section{Conceptualizing global climate governance}

In general terms, climate governance is the structure of authority that encompasses global climate policy: as a mode of governance, rather than simply government, it involves a range of state and non-state players, and is a field of practice rather than simply a set of institutions. As with any mode of authority, as opposed to coercion, climate governance is grounded in principles of justice. Climate governance develops through contestations over these principles, between 'official' and 'non-official' versions: principles emerge and change, from the process of interstate negotiation to civil society mobilization. Approaches to global governance invariably conceive of it as bringing order to disorder, whether by increasing the 'density' of interstate society, or by expressing the leverage of global civil society (Held \& McGrew 2002). By focusing on reflexivity this paper seeks to invert the frame, and foreground the challenges to governance. Clearly there are multiple structural challenges to climate policy, as much from intended as unintended effects: the focus here is on the process of 
reconceptualizing justice claims, in part to address these effects. The aim is to address climate governance as both a disordering and ordering process, analyzing the role of contestation in producing justice principles and practices.

Climate change imposes its own pace of policy reform, forcing new imperatives; it also imposes its own remarkable scope, in terms of global reach and all-encompassing depth. The resulting justice challenges are manifold, and resonate across a range of disciplines. The focus on reflexive governance most directly engages with critical international relations and globalization studies. The two dominant traditions in international relations theory_-'realism' and 'idealism' - are preoccupied principally with the question of whether state or non-state actors are dominant (Walker 1993). Critical international relations, instead, addresses the process of exercising power and counterpower at all levels (Halliday 2001). Related approaches to interpreting global governance have also emerged from other social science disciplines that investigate globalization across national-international divides (McGrew 1997). Within these fields there is a clear distinction between 'globalization theory,' which positions globalization as a cause of the changes it brings, and the 'theory of globalization' that seeks to explain globalization itself (Rosenberg 2000). These latter, more critical approaches to globalization studies, dovetail with approaches in critical international relations, and offer a rich inter-disciplinary frame.

The relationship between global governance discourses and contending social forces is a focus, especially, of the neo-Gramscian international relations tradition, which positions the governance-contestation nexus as the key explanatory site of global politics (Cox 1987; Cox 2001; Gill 2002; Bakker \& Gill 2003; Rupert 2003; Carroll 2007). The aim is for constructive critique, and the generation of alternate principles and guides to action, in order to address climate change and realizing climate justice. Debates about the extent to which climate change forces a refiguring of hegemonic formations, and the possibilities this offers for counter-hegemonic challengers, are intensifying, especially with the advent of North-South instruments of climate governance (Levy \& Egan 2003; Newell 2008; Paterson \& Newell 2010). The attempted monetization of greenhouse gas emissions, and the construction of the carbon commodity, allow new forms of marketization to offset mitigation. This neoliberalization of climate policy offers new sites for displacement from high emitters 
in the North, and from their Southern counterparts, and thus for new forms of contestation (Okereke 2008). ${ }^{2}$

In this way, North-South climate policy frameworks create transnational political spaces, which can be used to politicize ecological unevenness. As such, North-South relations in climate justice are simultaneously positioned alongside fields of postcolonial and critical development studies. Confronted by global environmental change the development problematic is redefined as a concern for over-consuming industrialized societies as well as for newly industrializing and under-developed societies (Robinson 2002; Biel 2000; McMichael 2003). This shared development crisis sets the mould for climate justice debates. Out of the confrontation between developmentalist and post-developmentalist models, where Southern and Northern exemplars are set against each other, has emerged a more explicitly 'reflexive' developmental frame, which rests on mutual recognition of shared problems and the pursuit of common targets (Pieterse 1998; 2004). Rather than looking to the North as a guide for development, or to the South for post-developmentalist scenarios, the 'reflexive development' approach finds new pathways at the nexus between North and South for confronting and addressing globalizing pressures.

The reflexive logic was exemplified by the 'global justice movement' that emerged in the mid-1990s, in which neoliberal globalism was identified as the shared problem of both North and South (Della Porta 2007). This allowed the identification of common targets, including interstate agencies charged with implementing those precepts (Starr 2000; Reitan 2007). Neo-liberal global governance, and its failures, generated a protest cycle expressed in the global justice movement (Cohen \& Rai 2000; Smith 2002; Tarrow 2005; Eschle 2005; Juris 2008). With climate change, as noted, the antagonism is driven by a deeper eco-systemic crisis, signaling the 'revenge of nature' on a planetary scale (Anderson 2006). Consequently, with the associated 'climate justice movement' there is a deeper and more existential community of fate. Again, challenges are articulated in the form of shared problems, aspirations, and targets (Roberts \& Parks

\footnotetext{
2 'North' or 'Global North,' and 'South' or 'Global South,' are used here to simultaneously recognise social and spatial inequalities: most low-income societies are in the Southern Hemisphere, but the 'South' is also global, with extreme poverty also in the Northern Hemisphere; likewise for the high-income 'North', which is both spatially concentrated and globalized. As discussed in this article, the ambiguity of these categories is increasingly played-out in the dynamics of inter-state climate policy.
} 
2006). In this context climate justice emerges as a particularly powerful expression of 'reflexive development' on a world scale.

Reflexivity rests in movements, and when it comes to questions of political agency, accounts of global social action replicate long-running debates about the relative importance of instrumental as against expressive action (Buechler 2000; Della Porta and Tarrow 2005; Macdonald 2006). With climate action movements, research reveals a strong instrumental theme, centring on the rhetoric-reality gap in climate policy (Hall $\&$ Taplin 2007). This affirms a 'political opportunities' model of social movement mobilization where movements are interpreted as rational actors responding to institutional failure (Van Der Heijden 2006). At the same time, there can be strong expressive dimensions to climate action as a form of ethical action: here climate action can be an end in itself, an intrinsic defence of ethical values in the face of climate injustice (Connor et al 2009). As with other movements, the two dimensions are interwoven and play-out in ways that reflect the history and context of local mobilization (Calhoun 1993).

There is, indeed, a key place-based dimension to the mobilization of climate justice claims, and thus to global climate governance. In climate governance the contradictions between policy and practice are most evident in particular sites of carbon policy: a geography of carbon policy can be traced from expanding carbon-intensive infrastructure in the North, to carbon trading finance houses, and then to 'clean development' offset sites located in the South (Roberts \& Tofflon-Weiss 2001; Chatterton 2005; Plows 2008). Climate action, then, is enacted in specific places, where the concrete instances of climate policy failure are manifested. Such sites acquire a meaning that is simultaneously local and global, reflecting the spatial politics of climate change (Seel 1997; Griggs \& Howarth 2004; Pickerill \& Chatterton 2006; Bosso \& Guber 2006;). As generative sites, these can be conceptualized as places where new insights emerge, and new justice claims are produced (Johnston \& Goodman 2006; Massey 2007). Here, the territoriality of climate policy becomes a key dimension of politicization and mobilization (Brenner 2004; Drainville 2004; Harvey 2010).

\section{Official and non-official climate justice}

The impact of climate change has been likened to that of a third world war, one at least as devastating as its predecessors. In this war the Global South is in the immediate 
firing line: the impacts of climate change for low-income peoples are now predicted to be disproportionate and catastrophic. In April 2007 a Report issued by the Intergovernmental Panel on Climate Change (IPCC) on impacts and vulnerability stated that in the South, where urbanization and industrialization are already putting pressure on resources and where adaptation capacity is relatively weak, climate change will have its most immediate negative impact (Parry et al. 2007). The Report predicted major water shortages due to climate change, with a potential halving in agricultural production in some regions of Africa by 2020, and a one-third reduction in yields in Central and South Asia by 2050, as well as inundation of the densely populated megadeltas of South and South-East Asia due to rising sea levels.

In this context, those amongst Northern and Southern elites who continue to benefit from continued accumulation do so at an immediate and measurable cost to Southern peoples. But there is a sting in the tail: as nature wreaks its revenge a climate breakdown from which even the richest cannot insulate themselves, is now only a generation away. The UN Human Development Report for 2007, 'Fighting climate change,' underlines the point:

Climate change is the defining human development challenge of the 21 st Century. Failure to respond to that challenge will stall and then reverse international efforts to reduce poverty. The poorest countries and most vulnerable citizens will suffer the earliest and most damaging setbacks, even though they have contributed least to the problem. Looking to the future, no countryhowever wealthy or powerful—will be immune to the impact of global warming. (UNDP 2008: 1)

The asymmetries of cause and effect in climate change directly reflect global development divides, making the question of how to address climate change unalterably a question of justice. As noted, the inter-governmental Climate Change Convention and Kyoto process was primarily directed at Northern climate change culprits with the aim of reducing their emissions. The impact of that effort has been minimal - securing at best a one per cent reduction in overall anticipated global GHG emissions from 1992 levels (Christoff 2006). The key impact of Kyoto, however, was to create frameworks that enable the displacement of restructuring costs from North to South, through carbon trading. The UN's 'Clean Development Mechanism,' for instance, certifies development projects that offset for rising greenhouse gas emissions in Annex 1 countries. All such projects operate to displace Northern costs, re-gearing Southern developmentalism to Northern needs. Driven by external financial imperatives rather than local ecological or developmental needs, their principal effect is 
to disrupt and distort Southern societies, to support GHG polluters in the North, and to create windfall profits for carbon traders (Lohmann 2006).

In many respects, however, this model is unraveling. There are two elements: first, the emergence of Southern emitters; and second, the increasing incidence of impacts, especially in Southern settings. The 1992 Convention rested on a model of climate justice that located the victims in the South and the culprits in the North, with Northern countries bearing historic responsibility and producing about three-quarters of 1992 emissions (Jordan 1994). That model is now heavily qualified by the fact that since 2007 non-Annex 1 countries responsible for the majority of the world's current emissions, and thus must be part of any agreement to reduce overall emissions (Barker et al 2007).

At one level the growing importance of non-Annex 1 countries is reflected in a rapid process of bidding-up funding commitments: since the mid-2000s Northern agencies and states have made increasingly generous offers of 'adaptation' funding, linked to Southern compliance with Northern mitigation models and priorities. In 2006, for instance, the World Bank linked the privatization of Southern energy and resources sectors with financial support to enable what it called 'climate-resilient development,' estimating Southern annual climate adaptation needs at up to $\$ 40$ billion (World Bank 2006). Four years later a major World Bank investigation into adaptation costs recalulated the estimate at between $\$ 70$ and $\$ 100$ billion per year (World Bank 2010). The World Bank estimates compare unfavourably with the $\$ 10$ billion a year offer under the 'Copenhagen Accord.'

The Accord was assembled by the USA in the closing days of the 2008 UNFCCC Conference of the Parties held in Copenhagen, and marked a significant attempt to break away from the consensual United Nations negotiating process. The Accord echoes responses to the New International Economic Order in the early 1970s, which was effectively countered by Northern offers of development aid, and by a breakaway Northern configuration, the 'Group of Six' major economies, which began meeting formally in 1975 (Biel 2000). Unlike the 1970s, however, the breakdown at Copenhagen in 2009 should not be interpreted as the endgame, but rather as the initial skirmish in a major power shift, driven by the geopolitics of emissions. That geopolitics is now forcing a move beyond the 'Thirdwordism' expressed in the division between 
Northern and Southern responsibilities, and towards a new mutual responsibility. The advent of a reciprocal ecological interdependency between Northern and Southern societies contrasts dramatically with the logic of developmental dependency. Rather than the South depending on the North, North and South now depend on each other. The confrontation between capitalist development and ecological survival expressed in advancing climate change is thus creating a new meta-imperative to live differently: the imperative creates a new inter-dependency, where, put simply, all societies depend on each other's willingness and capacity to shift from carbon-intensive accumulation.

This reflexive dynamic of climate justice has major implications for the governance model. As long as climate justice was framed mainly in terms of interstate responsibilities and obligations, its political logic could be confined and delimited. With the North defined as the principal culprit, the bulk of non-official influence on the governance process was North-centred and was deployed under the generic rubric of 'climate action', for instance through the 'Climate Action Network' which was established in 1988 (Pearce 2010). With the unraveling of the model established under the Framework Convention, new forms of political engagement and approaches to climate justice have emerged. Faced by growing disorder in the interstate governance process, climate politics has been forced out of the interstate container and has become subject to wider influences. Several factors are at play. Most important is the failure of policy and the first signs of large scale impacts on Southern peoples. Additionally, with the emergence of Southern elites as key players in the interstate political process, new unofficial counterpoints have emerged, through transnational climate justice politics. The result, at Muller observes, is that climate justice has increasingly revitalized and subsumed the pre-existing global justice movement (Muller 2008).

\section{Unofficial climate justice}

Climate Justice was first enunciated as a global set of principles at the United Nations World Summit on Sustainable Development, held in Johannesburg in August 2002 (India Resources Centre 2002). The twenty-seven Principles of Climate Justice were written by a group of fourteen Northern and Southern NGOs, including CorpWatch, Friends of the Earth International, Greenpeace International, the Indigenous Environmental Network, and the Third World Network. The Principles of Climate Justice foregrounded ecological debt, stating that Northern states and corporations 'owe 
the rest of the world as a result of their appropriation of the planet's capacity to absorb greenhouse gases' (India Resources Centre 2002:1). Stronger involvement from affected peoples in the South was a priority, to allow local control and conservation with 'clean, renewable, locally controlled and low-impact energy'; commodification and corporate influence were rejected, but market solutions were acceptable provided they conformed to 'principles of democratic accountability, ecological sustainability and social justice' (India Resources Centre 2002: 1).

The critique of 'false solutions,' in particular emissions trading, was developed more strongly with the Durban Climate Justice Summit held in 2004. Linked to the Durban group 'Carbon Trade Watch,' the Summit gathered twenty organizations from Europe, the USA, Latin America, India and Africa. The resulting 'Durban Declaration on Carbon Trading' outlined the various ways in which emissions trading both undermines existing sustainable practices and contributes to climate change, thus highlighting the irony that 'the Earth's ability and capacity to support a climate conducive to life and human societies is [sic] now passing into the same corporate hands that are destroying the climate' (Carbon Trade Watch 2004). Subsequently the Declaration attracted support from a further 163 organizations, and given the growing importance of emissions trading, its message had a strong influence.

Drawing these players together, a 'Climate Justice Now!' coalition was established in December 2007 at the Bali 'Conference of Parties to the UN Framework Convention on Climate Change (UNFCCC).' The coalition included a range of Southern and Northernbased NGOs and social movements that had played a central role in global justice, such as Focus on the Global South, the International Forum on Globalization, La Via Campesina, the World Development Movement and Third World Network, as well as signatories of previous climate justice statements. At the Bali UNFCCC the group issued a simple statement critical of 'false solutions ... such as trade liberalisation, privatisation, forest carbon markets, agrofuels and carbon offsetting,' stressing instead the need to leave carbon in the ground, reduce elite consumption, entrench resource rights, pursue food sovereignty, and repay climate debts through North-South wealth transfers (Climate Justice Coalition 2007). The following year, at the UNFCCC in Poznam, the coalition produced a more critical position, asserting 'we will not be able to stop climate change if we don't change the neo-liberal and corporate-based economy 
which stops us from achieving sustainable societies' (Climate Justice Now! 2008). The UNFCCC process needed to make a break with 'market ideology' and instead looked to sustainable practices in the South, as 'effective and enduring solutions will come from those who have protected the environment' such as peasants, women and indigenous peoples.

Also at Bali in 2007, a campaign network established a process for the 'Peoples' Protocol on Climate Change' (Asia-Pacific Research Network 2007). The Protocol defined climate change as 'a question of social justice ... rooted in the current capitalist-dominated global economy which is principally driven by the relentless drive for private profits and accumulation' (Asia-Pacific Research Network 2007:2). Accordingly it rejected 'market mechanisms that impose the cash nexus on ecological priorities,' and was critical of technological fixes. The Protocol asserted peoples' resource sovereignty, and the need for affected peoples to be involved in climate policy, and stated that the "climate change crisis is not simply about adaptation and mitigation, but changing the whole economic framework into one of eco-sufficiency and sustainability’ (Asia-Pacific Research Network 2007:3).

The Protocol process and the Climate Justice Now! Coalition opened several lines of debate in the broader climate justice movement, centring on issues of growth, sufficiency, technology, markets, sovereignty and climate debt. The debates were defined in relation to emerging climate policy, but in the run-up to Copenhagen in 2009 they began to establish a distinct ideological field. Mobilizations at Copenhagen through Clima Forum, for instance, saw this emergent movement announce itself as an alternative source of legitimacy on climate governance - a claim that gained traction in the context of a failing interstate process. In a development not unlike the linkage between global justice protesters and Southern states at the Seattle WTO in 1999, Southern states blocked Northern efforts to dissolve the UNFCCC model of climate justice and staged a walk-out, with many official representations joining unofficial protesters on the 'outside.' But perhaps more important for the long-term development of climate justice principles, inside the negotiating hall some 100 states joined with the Alliance of Small Island States in calling for emissions reductions that would prevent average temperatures rising more than 1.5 degrees Celsius, thus breaking with the prevailing consensus that a rise of 2 degrees was acceptable, despite its impacts. 
With these developments we have seen the centre of gravity for unofficial climate governance passing from a transnational climate advocacy network focused on the interstate process (expressed in the international Climate Action Network), to a heterogeneous climate justice movement that challenges climate governance through a transnational collective consciousness and capacity to mobilize (see Keck \& Sikkink 1998). In what follows this capacity is explored through an exploration of sites of climate justice, North and South.

\section{Generative sites, North and South}

Generative sites for climate justice, both North and South, are in the first instance sites of climate policy failure. As sites of failure, they are nonetheless also sites of possibility. In this respect the disorders of climate governance are themselves generative. In both North and South the physical manifestations of climate policy failure most dramatically undermine the legitimacy of the official model, and prefigure new approaches.

\section{Northern Sites}

One of the most powerful Northern examples, originating in the UK in 2006, is the phenomenon of the 'Camp for Climate Action.' As a form of strategic direct action the 'climate camp' model was taken up in a number of Northern countries, in the USA for instance as 'climate convergence,' and became something of a climate justice template (Plows 2008; Saunders \& Price 2008). Climate camps are a form of mass occupation, in the first instance spatial interventions, mounted as close as possible to the physical site of large-scale carbon emissions. The Camp is often directed at contesting the expansion of carbon-emitting infrastructures, whether by (temporarily) closing them down or by simply posing an alternative. In this way, the Camp exploits contradictions between the policy and practice of climate governance, and becomes in itself an embodied symbol of climate justice (Roberts \& Tofflon-Weiss 2001; Chatterton 2005; Plows 2008).

The UK's climate camps in the years 2006-2009 centred on preventing the expansion of coal fired power stations at Drax (2006), Kingsnorth (2008) and Ratcliffe on Soar (2009), and on halting the third runway at Heathrow airport (2007). In two casesKingsnorth and Heathrow_planned expansions were shelved, suggesting the mobilizations had their effect on policy, as well as contributing to the process of movement building. The Kingsnorth mobilization, for instance, was linked to a 
campaign by the World Development Movement, which characterized the power station not simply as a negation of the UK's Kyoto commitments, but as a violation of global climate justice principles. On a world scale, the World Development Movement calculated that the additional emissions resulting from the expansion of the power plant would have the following direct impacts:

- $\quad 100,000$ more people losing their dry season water supply

- $\quad$ Up to 300 more people dying every year due to malnutrition

- $\quad$ Up to 60,000 more people suffering from drought in Africa

- $\quad 50,000$ more people going hungry due to drought and lower crop yields

- $\quad$ Up to 40,000 more people exposed to malaria

- $\quad 20,000$ people being forced our of their homes and becoming climate refugees

- $\quad$ Around 30,000 more people losing their homes every year due to coastal flooding. (WDM 2009)

More broadly, the Camps were surprisingly successful in constructing counter-sites, designed to unmask and contest plans to expand carbon-intensive infrastructures and industries (Newell 2008). As such, carbon hotspots become physical manifestations of climate policy failure, their meaning thus transformed: from functional mechanisms they become reconfigured as threats to planetary survival (a similar approach was observed for anti-road protests: Seel 1997). The low walls and fences that skirt the facilities, protecting people from the heavy machinery, become highly politicized boundaries protecting the facilities from climate justice claims. As their existence is challenged, the sites acquire intense symbolic meaning, their boundaries acquiring a simultaneously local and global resonance (Bosso \& Guber 2006).

These otherwise ordinary places become political places that symbolically 'lift the veil' on climate policy. Participation in such events is in this sense apocalyptic, designed to reveal what is real, through participation in collective action that models eco-centric living, through the creation of public and open spaces for reflection and debate on climate issues and how to address them, and through planning and mounting a series of direct actions against climate change perpetrators. Conceptualized as a generative site, or as a social laboratory, the Camp is defined as a place where people experience their own power, and where new visions and possibilities are produced (Johnston \& Goodman 2006). What emerges is an embodied and emplaced spatial politics of climate change, a climate micro-politics perhaps, embedded in the macro-politics of globalized climate change. 


\section{Southern sites}

Southern climate justice movements are likewise focused on the injustices of climate policy, and are similarly centred on specific sites. Where Northern unofficial climate justice focuses on the failure to take responsibility for Northern emissions, Southern counterparts focus on the corollary, that is, the effort to displace responsibility for Northern emissions reductions onto Southern societies. Again, North-South connectivity is central: it is no accident that unofficial climate justice has emerged at the same time as international carbon markets have begun to create offset projects in Southern contexts (Bond 2006). A direct North-South linkage is created, through climate governance under Kyoto, between expanded emissions in Northern contexts and 'low cost' carbon offset projects in the South. That connection is reflected in the Durban 'Carbon Trade Watch' group, which, as already noted, has played a central role in the emergent climate justice movement (Bond \& Dada 2007).

Offset projects established under the Kyoto-endorsed 'Clean Development Mechanism' (CDM) have played a key role, as has the proposed UN 'Programme for Reducing Emissions from Deforestation and Forest Degradation in Developing Countries' (REDD). With the internationalization of emissions trading, offsetting has enabled a process of bidding-down the cost of emissions reduction in the search for cheapest perton emissions reductions (exactly what carbon markets are designed to achieve). As demonstrated by the up-take in Southern offsets by EU countries in particular, the cost of emissions reduction under the CDM is considerably lower than the cost of emissions reductions 'at home.' Cheaper still are offsets for reduced deforestation, under the proposed REDD regime, which simply seeks to maintain or 'sustainably manage' existing forests. The Stern Report, for instance, pointed to REDD credits as a 'highly cost-effective way to reduce emissions,' and, not surprisingly, a number of high emitting countries have since sought to extend recognition to forests under the proposed post-Kyoto framework (Stern 2007: 537). Indeed, REDD initiatives have spawned more than twenty programs under a variety of funding mechanisms.

Measures to reduce deforestation and degradation are clearly an important aspect of any global response to climate change. Deforestation and degradation of forests increase global emissions not just by the burning of wood, but also by allowing the decomposition of soil carbon, and reducing the planet's capacity to absorb $\mathrm{CO} 2$ as well. 
The Intergovernmental Panel on Climate Change estimates the net effect of these forest emissions to be about 17 percent of global emissions, with half of this coming from low-income developing countries in the tropics, such as Indonesia, that retain substantial tracts of forest. The key issue rests, however, not on whether to prevent the loss of these forests, but on whether programs to achieve this can be used to generate offset credits for continued or expanded emissions in the North (Reality of Aid 2009; Goodman \& Roberts 2009, 2011).

North-South offset mechanisms like CDM and REDD have, indeed, been targeted as creating new structures of global dependency, what Carbon Trade Watch calls 'carbon colonialism' that reorientates development pathways to cater for the Northern carbon appetite. Further, both CDM and REDD are criticized for assuming commensurability between present emissions and future increases in sink capacity, or reductions in projected emissions. There are also concerns about the vulnerability of offset schemes to the carbon market and to carbon speculators. Offsets are seen as linking emissions reductions to highly volatile carbon prices, empowering a new class of carbon financiers (Friends of the Earth International 2008). REDD, in particular has enormous scope, as it is potentially applicable to any significant Southern forest. Not surprisingly, the immediate impact on the peoples who live in forests, exercise ancestral domain over them, and rely on them, has become a major issue. In empowering carbon traders, REDD is seen to jeopardize the sovereign rights of people who have historically conserved forests, and to serve as a charter for their dispossession (International Forum of Indigenous Peoples on Climate Change 2008).

There is a growing political revolt against carbon offsets from within countries, such as Indonesia, that are emerging as key sites for such projects (see Indonesian Forum on the Environment, WALHI, 2009). Contestation of REDD projects, and also of CDMs, centres on local contexts - articulated through transnational networks - with Southern sites politicized in confrontation with official frameworks. One example is the challenge to REDD projects in Kalimantan, Indonesia, that have been funded by the Australian Government to lay the groundwork for the recognition of carbon credits (see Goodman \& Roberts 2010). The schemes are defined as violating justice principles, form the 'polluter pays' principle to issues of historical obligation and resulting 'carbon debt.' The world's current reliance on the sink and carbon storage capacity of the 
world's remaining forests reflects the logic of global ecological injustice, with those who have benefited from the worldwide release of greenhouse gases arraigned against those who now are required to suffer the consequences. Offsets, therefore, are seen as compounding these climate injustices.

\section{Conclusions}

Despite the broad structural context of a newly reciprocal imperative for global development, as imposed by climate change, it must be acknowledged that many of the possibilities for disordering prevailing climate governance remain unrealized. The barriers to unofficial climate justice, and thus to reflexive global climate governance, should not be underestimated. The sheer scale of, and system-wide challenge posed by, climate change are themselves demobilizing. In Northern contexts there is an additional sense of complicity: here, rather than producing a climate movement, the intensifying crisis can produce a form of 'apocalypse blindness' (Beck 1995; Depledge 2006). In many contexts climate consciousness can exist as a latent subjectivity, where publics share an awareness of contradictions but fail to engage in social action (Doherty 2002; Norgaard 2006; Boycoff 2008). A tension can build up, but remain internalized, with the resulting crisis of belief embedded in everyday subjectivity, but repressed from public policy (Agyeman \& Evans 2004; Dorsey 2007). We witness the deferral of social power to the public authorities, by which climate change is framed as a problem for policy elites and only incidentally for their increasingly anxious constituencies.

In this scenario the constitutive power of social agency, an historical actor capable of remaking society, remains unrealized. Something of the scale of the problem in the North is reflected, for instance, in concern at the lack of mass mobilization expressed by the UK Energy and Climate Change Minister (and later Shadow Prime Minister), Ed Miliband, in December 2008:

\footnotetext{
When you think about all the big historic movements, from the suffragettes, to anti-apartheid, to sexual equality in the 1960 s, all the big political movements had popular mobilization. Maybe it's an odd thing for someone in government to say, but I just think there's a real opportunity and a need here. (Adam \& Jowitt 2008; see also Hinsliff \& Vidal 2009)
}

Nevertheless, as suggested in the foregoing examples, the injustices of official climate governance can provide the antidote to passivity. The injustices of climate change are distanced from everyday experience, embedded in centuries of global uneven 
development as a structural 'fact of life,' and normalized as inevitable. In contrast, the injustices of official climate governance are present, manifest, and concrete. As climate crisis intensifies there is a sharpened contradiction between official acknowledgement of the growing problem and the inadequate (often self-serving) policy responses. That contradiction is increasingly salient, especially across the North-South axis. Indeed, official climate injustice is the product of deliberate decisions: someone gains, someone looses, and both can be identified. There are clearly definable culprits, with specific installations and projects to be targeted, and disrupted. Herein, perhaps, lies the potency of unofficial climate justice claims, as a counterpoint to the official script, embedded in concrete social and ecological contradictions of climate policy.

\section{Reference List}

Adam, D. \& Jowitt, J. 2008, 'People Power Vital to Climate Deal: Miliband Calls for Global Movement to Pressure Governments into Action,' The Guardian, 8 December.

Agyeman, J. \& Evans, B. 2004, “"Just Sustainability”: The Emerging Discourse of Environmental Justice in Britain?,' The Geographical Journal, vol. 170, no. 2, 155-164.

Anderson, J. 2006, 'The Environment, “Anti-globalization,” and the Runaway Bicycle,' in Nature's Revenge: Reclaiming Sustainability in an Age of Corporate Globalisation, (eds) J. Johnston, M. Gismondi \& J. Goodman. Broadview, Toronto, 280-298.

Asia Pacific Research Network 2007, Peoples' Protocol on Climate Change, APRN, Manila.

Bakker, I. \& Gill, S. 2003, Power, Production and Social Reproduction. Palgrave, London.

Barker, T. et al. (eds) 2007, Climate Change 2007: Mitigation. Contribution of Working Group III to the Fourth Assessment Report of the Intergovernmental Panel on Climate Change. Cambridge University Press, Cambridge.

Beck, U. 1995, Ecological Politics in an Age of Risk. Polity Press, Cambridge.

Bennholdt-Thomsen, V. \& Mies, M. 1999, The Subsistence Perspective. Zed Press, London.

Biel, R. 2000, The New Imperialism: Crisis and Contradiction in North/South Relations. Zed Books, London.

Blowers, A. 1997, 'Environmental Policy: Ecological Modernization or Risk Society?', Urban Studies, vol. 34 , no. 5-6, 845-871.

Bond, P. 2006, 'Civil Society on Global Governance: Facing Up to Divergent Analysis, Strategy, and Tactics,' Voluntas, no. 17, 359-371.

Bond, P. \& Dada, R. 2007, Trouble in the Air: Global Warming and the Privatised Atmosphere. Transnational Institute, Amsterdam.

Bosso, C. and Guber, D. 2006, 'Maintaining Presence: Environmental Advocacy and the Permanent Campaign,' in Environmental Policy, (eds) N. Vig, \& M. Kraft, CQ Press, Washington, 78-91.

Boykoff, M. 2008, 'The Cultural Politics of Climate Change Discourse in UK Tabloids,' Political Geography, no. 27, 549-569.

Brenner, N. 2004, New State Spaces. Oxford University Press, Oxford.

Buechler, S. 2000, Social Movements in Advanced Capitalism: The Political Economy and Social Construction of Social Activism. Oxford University Press, New York

Calhoun, C. 1993, “New Social Movements” of the Early Nineteenth Century,' Social Science History, vol. 17 , no. $3,385-427$.

Carbon Trade Watch 2004, Climate Justice Now! The Durban Declaration on Carbon Trading, CTW, Durban.

Carroll, W. 2007. 'Hegemony and the Global Field.' Studies in Social Justice, vol. 1, no. 1, 36-66.

Chakrabarty, D. 2008, 'The Climate of History: Four Theses,' Critical Inquiry, no. 35, 11-62.

Chatterton, P 2005, “'Give Up Activism” and Change the World in Unknown Ways. Or, Learning to Walk with Others on Uncommon Ground,' Antipode, vol. 38, no. 2, 259-282. 
Christoff, P. 2006, 'Post-Kyoto? Post-Bush? Towards an Effective "Climate Ccoalition of the Willing," International Affairs, vol. 85, no. 2, 831-860.

Climate Justice Coalition 2007, Climate Justice Now! Principles, CJC, Denpasar.

Cohen, R. \& Rai, S. 2000, Global Social Movements. Athlone, London.

Connor, L., Higginbotham, N. and Freeman, S. 2009, 'Not Just a Coalmine: Shifting Grounds of Community Opposition to Coalmining in Southeastern Australia,' Ethnos, vol. 74, no. 4, 490-513.

Cox, R. 1987, Production, Power and World Order: Social Forces in the Making of History. Columbia University Press, New York. 2001, 'The Way Ahead: Towards a New Ontology of World Order,' Critical Theory and World Politics, (ed.) R. Wyn Jones. Lynne Rienner, Boulder, CO.

Crutzen, P. 2002, 'Geology of Mankind,' Nature, vol. 415, 23.

Della Porta, D. (ed.) 2007, The Global Justice Movement: Cross-national and Transnational Perspectives. Paradigm Publishers, Herndon, VA.

Della Porta, D. and Tarrow, S. 2005, Transnational Protest and Global Activism. Rowman and Littlefield, Lanham.

Depledge, J. 2006, 'The Opposite of Learning: Ossification in the Climate Change Regime,' Global Environmental Politics, vol. 6, no. 1, 1-22.

Doherty, B. 2002, Ideas and Action in the Green Movement. Routledge, London \& New York.

Dorsey, M. 2007, Climate Knowledge and Power, Capitalism, Nature, Socialism, vol. 18, no. 2, 7-21.

Drainville, A. 2004, Contesting Globalisation: Space and Place in the World Economy. Routledge, London \& New York.

Eschle, C. 2005, 'Constructing "the Anti-Globalisation Movement,"' Critical Theories, International Relations and the Anti-globalisation Movement, (eds) C. Eschle and B. Maiguashca. Routledge, London \& New York.

Foster-Carter, J. 2002, Ecology Against Capitalism. Monthly Review Press, New York.

Friends of the Earth International 2008, REDD Myths: A Critical Review of Proposed Mechanisms to Reduce Emissions from Deforestation and Degradation in Developing Countries, FoEI, Amsterdam.

Gill, S. 2002. Power and Resistance in the New World Order. Palgrave Macmillan, London.

Goodman, J. \& Roberts, E. 2009, What a Scam! Australia's REDD Offsets for Copenhagen. FoEA and AidWatch, Sydney 2011, 'Is the United Nations' REDD Scheme Conservation Colonialism by Default?,' International Journal of Water, vol. 5. no. 4, 419-428.

Griggs, S. \& Howarth, D. 2004, 'A Transformative Political Campaign? The New Rhetoric of Protest against Airport Expansion in the UK,' Journal of Political Ideologies, vol. 9, no. 2, 176-187.

Hall, N. and Taplin, R. 2007, 'Revolution or Inch-by-inch? Campaign Approaches on Climate Change by Environmental Groups,' Environmentalist, vol. 27, no. 1, 1-22.

Halliday, F. 2001, 'The Romance of Non-state Actors,' in Non-state Actors in World Politics, (ed.) W. Wallace. Palgrave Macmillan, London, 21-38.

Harvey, D. 1996, Justice, Nature and the Politics of Difference. Blackwell, Cambridge. 2010, The Enigma of Capital: And the Crises of Capitalism. Profile Books, London.

Held, D. 2006, 'Reframing Global Governance: Apocalypse Soon or Reform!' New Political Economy, vol. 11 , no. $2,58-74$.

Held, D., \& McGrew, A. 2002, Governing Globalization: Power, Authority and Global Governance. Polity Press, Cambridge.

Hinsliff, G. \& Vidal, J. 2009, 'Miliband Calls for Populist Push on Climate Change,' The Observer, 26 April.

Hornborg, A. 2001, The Power of the Machine: Global Inequalities of Economy, Technology and Environment. Rowan and Littlefield, Lanham.

India Resources Centre 2002, Bali Principles of Climate Justice, International Climate Justice Network, Denpasar.

Indonesian Forum on the Environment, WALHI 2009, No rights no REDD. Walhi, Jakarta.

International Forum of Indigenous Peoples on Climate Change 2008, Statement of the IIPFCC, 14th Session of the Conference of the Parties of the United Nations Framework Conference on Climate Change, December 1, 2008.

Johnston, J. \& Goodman, J. 2006, 'Hope and Activism in the Ivory Tower: Freirean Lessons for Globalisation Research,' Globalisations vol. 3, no. 1, 9-30.

Jordan, A. 1994, 'Financing the UNCED Agenda: The Controversy over Additionality,' Environment, vol. 36 , no. $3,16-30$. 
Juris, J. 2008, Networking Futures: The Movements Against Corporate Globalization. Duke University Press, Durham, NC, \& London.

Keck, M. \& Sikkink, K. 1998, Activists Beyond Borders: Advocacy Networks in International Politics. Cornell University Press, Ithaca.

Kovel, J. 2007, The Enemy of Nature: The End of Capitalism or the End of the World. Zed Press, London.

Levy, David L. \& Daniel Egan 2003, 'A Neo-Gramscian Approach to Corporate Political Strategy: Conflict and Accommodation in the Climate Change Negotiations,' Journal of Management Studies, vol. 40, no. 4, 803-829.

Lohmann, L. (ed.) 2006, 'Carbon Trading: A Critical Conversation on Climate Change, Privatization and Power,' Development Dialogue, no. 48 (September), 1-362.

Massey, D. 2007, World City. Polity, Cambridge.

McDonald, K. 2006, Global Movements: Action and Culture. Blackwell, Malden, MA.

McGrew, A. 2007, 'Globalization in Hard Times: Contention in the Academy and Beyond,' in The Blackwell Companion to Globalization, (ed.) G. Ritzer. Blackwell, Malden, MA.

McMicheal, P. 2003, Globalisation. Cambridge University Press, Cambridge.

Moll, A. 2000, 'Ecological Modernization Around the World: An Introduction,' Environmental Politics, vol. 9 , no. $1,1-16$.

Muller, T. 2008, 'The Movement is Dead, Long Live the Movement,' Turbulence: Ideas for Movement, July 2008, 48-55.

Newell, P. 2008, 'Civil Society, Corporate Accountability and the Politics of Climate Change,' Global Environmental Politics, vol. 8, no. 3, 122-153.

Norgaard, K. 2006, “"We Don’t Really Want To Know”: Environmental Justice and Socially Organized Denial of Global Warming in Norway, Organization \& Environment, vol. 19, no. 3, 347-370.

Okereke, C. 2008, Global Justice and Neolioberal Environmental Governance. Routledge, London \& New York.

Parry, M, Canziani, O. and Palutikof, J. (eds) 2007, Climate Change 2007: Impacts, Adaptation and Vulnerability. Contribution of Working Group II to the Fourth Assessment Report of the Intergovernmental Panel on Climate Change. Cambridge University Press, Cambridge.

Paterson M. \& Grub, M. 1992, 'The International Politics of Climate Change,' International Affairs, vol. 68 , no. 2, 293-310

Paterson, M. \& Newell, P. 2010, Climate Capitalism: Global Warming and the Transformation of the Global Economy, Cambridge University Press, Cambridge.

Pearce, R. 2010, 'Making a Market? Contestation and Climate,' Journal of Australian Political Economy, no. $66,166-198$.

Pickerill, J. \& Chatterton, P. 2006, 'Notes Towards Autonomous Geographies. Creation, Resistance and Self Management as Survival Tactics,' Progress in Human Geography, vol. 30, no. 6, 730-746.

Pieterse, J. 1998, 'My Paradigm or Yours? Alternative Development, Post-development, Reflexive Development,' Development and Change, no. 29, 243-373. 2004, Globalization or Empire? Routledge, London \& New York.

Plows, A. 2008, 'Towards an Analysis of the 'Success' of UK Green Protests,' British Politics, vol. 3, no. $1,92-109$.

Reality of Aid 2009, Financing Climate Change Mitigation: Adaptation and Sustainable Development. Reality of Aid Asia, Manila.

Reitan, R. 2007, Global Activism. Routledge, New York \& London.

Roberts, J. \& Parks, B. 2006, A Climate of Injustice: Global Inequality, North-South Politics, and Climate Policy. MIT Press, Cambridge.

Roberts, T. \& Toffolon-Weiss, M. 2001, Chronicles from the Environmental Justice Frontline. Cambridge University Press, NY.

Robinson, W. 2002, 'Remapping Development in the Light of Globalisation: From a Territorial to a Social Cartography,' Third World Quarterly, vol. 23, no. 6, 1047-1073.

Rosenberg, J. 2000, Follies of Globalisation Theory. Verso, London.

Rupert, M. 2003, 'Globalising Common Sense: A Marxian-Gramscian (Re-)vision of the Politics of Governance/Resistance,' Review of International Studies, no. 29, 181-198.

Salleh, A. 1997, Ecofeminism as Politics: Nature, Marx and the Postmodern. Zed Press, London.

Saunders, C. 2008, 'The Stop Climate Chaos Coalition: Climate Change as a Development Issue,' Third World Quarterly, vol. 29, no. 8, 1509-1526.

Saunders, C. \& Price, S. 2009, 'One Person's Eu-topia, Another's Hell: Climate Camp as a Heterotopia,' Environmental Politics, vol. 18, no. 1, 117-122.

Seel, B. 1997, 'Strategies of Resistance at the Pollock Free State Road Protest Camp, Environmental Politics, vol. 6, no. 4, 108-139. 
Smith, J. 2002, 'Bridging Global Divides? Strategic Framing and Solidarity in Transnational Social Movement Organizations,' International Sociology, vol. 17, no. 4, 505-528.

Sousa-Santos, B. 1995, Toward a New Common Sense: Law, Science and Politics in the Paradigmatic Transition. Routledge, New York.

Starr, A. 2000, Naming the Enemy: Anti-corporate Movements Confront Globalization. Zed Press, London.

Stern, N. 2007, The Economics of Climate Change: The Stern Review. Cambridge University Press, Cambridge.

Tarrow, S. 2005, The New Transnational Activism. Cambridge University Press, Cambridge.

UNDP 2008, Fighting Climate Change, Human Development Report 2007, UNDP, New York.

Van Der Heijden, H. 2006, 'Globalization, Environmental Movements, and International Political Opportunity Structures,' Organization \& Environment, vol. 19, no. 1, 28-45

Walker, R. 1993, Inside/outside International Relations ad Political Theory. Cambridge University Press, Cambridge.

World Bank 2006, 'Clean Energy and Development: Towards an Investment Framework,' World Bank, Environmentally and Socially Sustainable Development and Infrastructure Vice Presidencies, World Bank, Washington DC. 2008, 'Economics of Adaptation to Climate Change: Global Cost Estimate,' World Bank, Washington DC.

World Development Movement 2009, 'World Development Movement Hails Kingsnorth Victory for People and Campaigners from Developing World and Kent,' 8 October.

Ziai, A. (ed.) 2007, Exploring Post-development: Theory and Practice, Problems and Perspectives. Routledge, London. 